\title{
PEMBAHARUAN SISTEM PENYELENGGARAAN PEMILIHAN KEPALA DAERAH YANG BERKUALITAS SELAMA MASA PANDEMI COVID-19
}

\author{
Lili Suriyanti \\ Fakultas Hukum, Universitas Sultan Ageng Tirtayasa \\ e-mail: lilisuryanti2019@gmail.com \\ Edi Mulyadi ZS \\ Fakultas Hukum, Universitas Sultan Ageng Tirtayasa \\ e-mail:naonjing@gmail.com
}

\begin{abstract}
ABSTRAK
Pemilukada merupakan perwujudan kedaulatan rakyat yang dilaksanakan secara demokratis meskipun dalam prakteknya Pemilukada langsung justru dapat menimbulkan biaya tinggi. Sistem penyelenggaraan Pemilukada harus dijalankan secara demokratis agar efektifitas dan kepastian hukum terjamin dengan peran Kepala Daerah yang berkualitas dan mampu melakukan perubahan di bidang sosial, ekonomi, dan politik di wilayahnya. Penelitian yuridis normatif dengan metode pendekatan perundang-undangan dan pendekatan konsep yang kemudian dianalisa secara deskriptif kualitatif. Sistem penyelenggaraan Pemilukada langsung tetap dipertahankan melalui pola asimetris dan/atau delegasi dengan memperhatikan tingkat kerawanan praktek politik uang dan tingkat kerawanan konflik horizontal di masing-masing daerah yang diatur oleh undang-undang. Implementasi pemilukada langsung ini perlu didukung dengan "pengadilan khusus" di setiap daerah untuk menangani sengketa Pemilukada dan penanganan tindak pidana pemilu guna terwujudnya kepastian hukum. Penelitian ini menyarankan perlunya rekonstruksi kebijakan pemilu daring serta dilakukan perubahan syarat pendidikan minimal sarjana, lulus uji publik yang dilaksanakan dari internal partai maupun uji publik oleh KPUD dengan melibatkan unsur masyarakat demi terpilihnya Kepala Daerah yang berkualitas.
\end{abstract}

Kata Kunci: Pemilukada; Kepala Daerah; Pandemi

\section{ABSTRACT}

Pemilukada is a manifestation of people's sovereignty which is implemented in a democratic manner, although it can cause high costs in practice. The Pemilukada implementation system must be implemented in a democratic manner so that the effectiveness and legal certainty is guaranteed by the role of a district head who is qualified and able to make changes in the social, economic, and political fields in spesific region. This normative juridical research uses a statutory and conceptual approachthen analyzed descriptively qualitatively. Pemilukada implementation system is maintained through an asymmetrical pattern and/or delegation by taking into account the level of vulnerability in money politics practices and the level of vulnerability to horizontal conflicts in each region as regulated by law. The implementation of this direct post-conflict local election needs to be supported by "special courts" in each region to handle election disputes and handling election crimes in order to realize legal certainty. This research suggests the need for online election policy reconstruction as well as changes to the minimum education requirements of undergraduate degrees, passing public tests carried out from internal parties as well as public tests by KPUD involving elements of society for the election of a quality regional head.

Keywords: Pemilukada; District Head; Pandemic 


\section{PENDAHULUAN}

Pemilihan umum Kepala Daerah dan Wakil Kepala Daerah (selanjutnya disebut Pemilukada) menjadi salah satu instrumen dalam mewujudkan pemerintahan daerah yang demokrasi serta mendasarkan pula pada prinsip kedaulatan rakyat. ${ }^{1}$ Berdasar pada prinsip demokrasi, maka pemilukada dapat meningkatkan kualitas demokrasi pada tingkat daerah. Pemilukada dapat membuka kesempatan peran masyarakat dalam proses memilih dan menentukan pemimpin di wilayahnya. Selanjutnya dari sisi kompetensi politik, Pemilukada langsung memungkinkan munculnya secara lebih lebar preferensi kandidat-kandidat berkompetensi dalam ruang yang lebih terbuka. Ketiga, aktualisasi hakhak politik menjadi lebih tersalurkan. Masyarakat juga secara langsung mendapat edukasi politik, dan kemampuan dalam mengambil keputusan. Keempat, pemilukada langsung memberikan kemungkinan dalam memperoleh figur yang kompeten, sekaligus lebih mengutamakan rakyat. Mampu meningkatkan kualitas tanggung jawab pemerintah daerah pada warganya, sehingga lebih dekat dengan masyarakat. Kelima, mempu membangun kekuatan yang seimbang dalam penyelenggaraan pemerintahan daerah, khususnya antara Kepala Daerah dengan DPRD, dengan berdasar pada prinsip check and balances. Mampu meminimalisir terjadinya penyalahgunaan kekuasaan. $^{2}$

Kenyataannya yang terjadi dari setiap penyelenggaraan Pemilukada menimbulkan berbagai permasalahan. Pemilukada secara langsung, mempunyai konsekuensi biaya yang tinggi dan terjadinya politik uang (money politics) sehingga memicu terjadinya korupsi pada saat telah resmi memegang jabatan sebagai Kepala Daerah. ${ }^{3}$ Terjadinya praktek korupsi yang dilakukan oleh kepala daerah disebabkan oleh beberapa faktor. Pertama, perilaku korupsi kepala daerah disebabkan

\footnotetext{
${ }^{1}$ Yusdianto. (2010). "Identifikasi Potensi Pelanggaran Pemilihan Kepala Daerah (Pemilukada) dan Mekanisme Penyelesaiannya". Jurnal Konstitusi. 2(2), h. 44.

${ }^{2}$ Suharizal. (2011). Pemilukada Regulasi, Dinamika, dan Konsep Mendatang. Jakarta: Rajawali Pers, h. 8-9.

3 Anonim. 2019. "Pilkada Langsung atau Tidak, Mau Dibawa ke Mana Demokrasi Kita?" https://www.kompas.com/ tren/read/2019/12/02/164404365/pilkada-langsung-atau-tidakmau-dibawa-ke-mana-demokrasi-kita? page =all. Diunduh tanggal 5 September 2020
}

oleh besarnya ongkos Pilkada langsung yang mereka keluarkan saat kampanye. Kedua, biaya negara yang tinggi dikeluarkan untuk penyelenggaraan pilkada langsung. Padahal menurutnya, saat ini negara memiliki prioritas utama untuk memajukan dan mencerdaskan sumber daya manusia, ketimbang menggelontorkan dana untuk Pilkada. ${ }^{4}$ Dengan demikian, Pemilukada yang diselengarakan secara langsung berpotensi melahirkan pemimpin yang lebih mementingkan kepentingan pribadi ketimbang kepentingan rakyatnya.

Berlatarbelakang dari permasalahan yang ditimbulkan dari penyelenggaraan Pemilukada secara langsung tersebut kemudian memunculkan kembali wacana Pemilukada tidak langsung yang kini tengah di evaluasi oleh Pemerintah melalui Kementerian Dalam Negeri. Namun, hal tersebut masih menimbulkan beragam pendapat, baik pro maupun kontra dari sejumlah kalangan Partai Politik hingga Ormas besar Islam, seperti Nahdlatul Ulama dan Muhammadiyah. Oleh karena itu, penting dalam penulisan ini untuk dianalisis mengenai pembaruan sistem penyelenggaraan Pemilukada, khususnya dengan memperhatikan pada situasi Pandemi Covid-19 sehingga diperlukan adanya inovasi, dengan menyesuaikan pada kondisi terkini sehingga apa yang diterapkan dalam Pemilukada selama pandemi Covid-19tetap mampu diimplementasikan saat situasi normal ketika Pandemi Covid-19 telah tiada baik untuk Pemilukada secara daring maupun Pemilukada langsung. Hal ini perlu memperhatikan pula pada kesiapan teknologi yang ada pada saat ini yan dikaitkan dengan penguatan dalam bidang hukum.

\section{PERUMUSAN MASALAH}

Bagaimana sistem penyelenggaraan Pemilukada yang efektif sehingga terjamin kepastian hukum bagi terselenggaranya pemilu yang demokratis di masa pandemi Covid-19, serta bagaimana sistem pemilihan Kepala Daerah yang berkualitas dalam rangka pembangunan ekonomi dan kemampuan

\footnotetext{
${ }^{4}$ Merdeka.com, "Alasan Kemendagri Evaluasi Pilkada Langsung, Banyak Kepala Daerah Terjerat Korupsi”, 21 November 2019. https://www.merdeka.com/politik/alasankemendagri-evaluasi-pilkada-langsung-banyak-kepala-daerahterjerat-korupsi.html. Diunduh tanggal 5 September 2020.
} 
manajemen krisis melalui Pemilukada di masa pandemi Covid-19.

\section{METODE PENELITIAN}

Penelitian ini merupakan penelitian yuridis normatif, dengan pendekatan peraturan perundangundangan (statute approach), dan pendekatan konseptual (conseptual approach). Berbagai bahan hukum yang diperoleh akan dilakukan analisis komprehensif dengan deskriptif kualitatif.

\section{PEMBAHASAN}

\section{Sistem Penyelenggaraan Pemilukada Yang Efektif Sehingga Terjamin Kepastian Hukum Bagi Terselenggaranya Pemilu Yang Demokratis}

Pemilihan Kepala Daerah wajib dilaksanakan secara demokratis, sebagaimana ditegaskan dalam Pasal 18 ayat (4) UUD 1945, "Gubernur, Bupati, dan Walikota masing-masing sebagai Kepala Pemerintah Daerah Provinsi, Kabupaten, dan Kota dipilih secara demokratis". Hal ini mengarahkan pada dua bentuk Pemilihan, yaitu secara langsung dan tidak langsung. ${ }^{5}$ Pemilihan Kepala Daerah (Pilkada) tidak langsung yaitu mendasarkan pada prinsip keterwakilan. Keberadaan DPRD telah dianggap sebagai representasi rakyat, sehingga pemilihan tidak langsung melalui DPRD, dinilai telah konstitusional. Mengingat pula bahwa pemilihan anggota DPRD dilakukan secara langsung oleh rakyat. ${ }^{6}$ Joseph Schumpeter menyebutkan, bahwa "demokrasi adalah sebuah mekanisme politik, diterapkan dalam pemilihan pimpinan politik. Para pemilih adalah yang sesungguhnya bersaing, guna memenangkan calon pemimpinnya". ${ }^{7}$

Pemilihan secara langsung adalah pemilihan oleh rakyat secara langsung dalam waktu yang bersamaan. Pemimpin yang terpilih adalah calon yang mendapat suara terbanyak. ${ }^{8}$ Sebagaimana pada Pasal 1 ayat (1) Peraturan Pemerintah Republik Indonesia Nomor 6 Tahun 2005 tentang Pemilihan, Pengesahan, Pengangkatan dan Pemberhentian Kepala Daerah juncto Peraturan Pemerintah Nomor 49 Tahun 2008

\footnotetext{
${ }^{5}$ Hendra Budiman. (2015). Pilkada tidak Langsung dan Demokrasi Palsu. Yogyakarta: Pustaka Yustisia, h.19.

${ }^{6}$ ibid., h. 161.

${ }^{7}$ George Sorensen. (2014). Demokrasi dan Demokratisasi (Proses dan Prospek dalam Sebuah Dunia yang Berubah). Yogyakarta: Pustaka Pelajar, h. 14.

${ }^{8}$ Hendra Budiman. op.cit., h. 161.
}

tentang Perubahan atas Peraturan Pemerintah Nomor 6 Tahun 2005 adalah: "sarana pelaksanaan kedaulatan rakyat di wilayah provinsi dan/atau Kabupaten/Kota berdasarkan Pancasila dan UUD 1945 untuk memilih kepala daerah dan wakil kepala daerah".

Kedaulatan rakyat yang dimaksud dalam rumusan di atas mengandung arti, kedaulatan atau kekuasaan tertinggi berada di tangan rakyat. ${ }^{9}$ Hasil Pemilukada tidak akan tercapai secara efektif apabila dalam sistem penyelenggaraan Pemilukada itu sendiri tidak dapat menjamin keadilan, kemanfaatan, dan berkepastian hukum. Mengutip pendapat Joko Prihatmoko, bahwa "sistem pemilihan yang dipilih harus dapat diterima semua pihak dengan cara menjamin keadilan, kejujuran, keterbukaan atau transparansi, dan kebebasan. ${ }^{10}$ Berdasar pada Pasal 2 Undang-Undang Nomor 7 Tahun 2017 tentang Pemilihan Umum (selanjutnya disebut UU Pemilu No. 7/2017) yang dijadikan sebagai asas penyelenggaraan Pemilu, yaitu langsung, umum, bebas, rahasia, jujur, dan adil. Sedangkan prinsipprinsip yang digunakan dalam penyelenggaraan pemilu, yaitu: mandiri, jujur, adil, berkepastian hukum, tertib, terbuka, proporsional, professional, akuntabel, efektif, dan efisien.

Belajar dari pengalaman, Pemilukada sejak tahun 2005, telah menyisakan berbagai masalah yang harus segera dilakukan pembaharuan. Timbulnya berbagai masalah dalam sistem penyelenggaraan yang sudah berjalan selama ini tidak terlepas dari adanya kelebihan dan kekurangan yang ada dalam pelaksanaan Pemilukada secara langsung yang dapat disandingkan dengan Pemilukada tidak langsung (melalui DPRD). ${ }^{11}$

Dilihat dari sisi kelebihan, merujuk pendapat Daniel Solosa bahwa kelebihan Pemilukada langsung antara lain: 1. Proses demokratisasi memang riil berjalan karena masyarakat akan terlibat langsung dan memantaunya; 2. Posisi Kepala Daerah akan cukup kuat (legitimated); 3. Terkesan lebih objektif; 4. Peluang terjadinya kasus money politics akan

\footnotetext{
${ }^{9}$ Jimly Asshiddiqie. (2011). Pengantar Ilmu Hukum Tata Negara. Jakarta: Rajawali Pers, h. 6.

${ }^{10}$ Joko Prihatmoko. (2003). Pemilu 2004 dan Konsolodasi Demokrasi. Jakarta: LP2I Press, h. 54.

${ }^{11}$ Ridho Imawan Hanafi. (2014). "Pemilihan Langsung Kepala Daerah di Indonesia: Beberapa Catatan Kritis Untuk Partai Politik." Jurnal Penelitian Politik 11(2).
} 
semakin tipis; 5. Sense of public accountability menjadi jelas. ${ }^{12}$

Berbeda dengan pendapat Daniel Solosa di atas, Abdul Bari Azed menyebutkan bahwa belum tentu apa yang disampaikan Daniel di atas mudah terwujud pelaksanaannya di lapangan karena: ${ }^{13}$

1. Sejumlah analis berkeyakinan, kelemahan pokok dari pemilihan yang ada sekarang diakibatkan adanya law enforcement belum secara tegas ditegakkan. Karena itu law enforcement menjadi kata kunci untuk ditegakkan tanpa pandang bulu;

2. Lebih objektif bisa jadi benar karena memang melibatkan banyak orang menentukan pilihan;

3. Peluang terjadinya politik uang masih tetap terbuka, artinya sistem langsung ini bukan jaminan membebaskan sepenuhnya money politics.

Dalam perkembangannya terdapat masalah yang krusial dalam penyelenggaraan Pemilukada. Pertama, tingginya biaya yang harus dikeluarkan, baik oleh calon peserta maupun oleh pemerintah. LSM Komite Pemantauan Pelaksanaan Otonomi Daerah (KPPOD) menemukan fakta di lapangan bahwa untuk tingkat Bupati setidaknya perlu mengeluarkan dana Rp.30 miliar, sementara untuk tingkat provinsi mencapai Rp.100 miliar. Harga rekomendasi Partai Politik untuk Bupati sebesar Rp.5 miliar, sedangkan harga rekomendasi untuk Calon Gubernur mencapai sebesar Rp.50 miliar. $^{14}$

Kedua, maraknya politik uang dalam penyelenggaraan Pilkada langsung masih relevan dengan kondisi saat ini. Pelaksanaan pemilukada di tengah situasi pandemi Covid-19 berpotensi terjadi pelanggaran di bidang money politic karena adanya relasi antara kepentingan politik dengan keadaan ekonomi masyarakat yang memburuk akibat pandemi. Money politics bukan hanya dengan modus berupa uang, sembako ataupun voucher namun bisa juga dalam bentuk pemberian bantuan alat kesehatan,

${ }^{12}$ Daniel Solosa. (2005). Pilkada Langsung. Jakarta: Media Presindo, h. 14.

${ }^{13}$ Abdul Bari Azed. (2005). Pemilu dan Partai Politik di Indonesia. Jakarta: PSH Tata Negara Universitas Indonesia, $\mathrm{h}$. 43.

${ }^{14}$ Anisyah Al Faqir. (2019). "Mahalnya Pilkada Langsung Hingga Habiskan Uang Rp 100 miliar". https://www.liputan6. com/bisnis/read/4134744/mahalnya-pilkada-langsung-hinggahabiskan-uang-rp-100-miliar. Diunduh tanggal 5 September 2020 . alat pelindung diri (APD), maupun bantuan sosial (bansos) baik secara langsung maupun transfer digital.Hal ini juga dapat memunculkan konflik horizontal pada penyelenggaraan Pilkada langsung. Pilkada langsung rentan menimbulkan konflik horizontal yang disebabkan karena perbedaan pilihan politik. $^{15}$

Berdasarkan pemaparan di atas, penyelenggaraan Pimilukada secara langsung dihadapkan pada 3 (tiga) persoalan krusial, yaitu mahalnya biaya politik, terjadinya praktek politik uang, dan timbulnya konflik horizontal karena perbedaan pandangan politik antar pendukung. Berdampak pada penyelenggaraan Pemilukada yang tidak mencerminkan kepastian hukum bagi terselenggaranya pemilu yang demokratis.

Setiap penyelenggaraan Pemilukada terdapat aturan-aturan yang tidak boleh dilanggar. Adanya praktek politik uang dalam setiap pelaksanaan Pemilukada secara prinsip telah bertentangan salah satu pasal dalam undang-undang pemilu, yaitu Pasal 2 UU Pemilu No. 7/2017 terkait dengan asas/ prinsip bebas, rahasia, jujur, dan adil. Asas "bebas" dalam memilih calon peserta sesuai dengan hati nuraninya menjadi bias, karena dengan politik uang menjadi hak memilih diarahkan untuk memilih calon peserta tertentu, sekalipun tidak sesuai dengan hati nuraninya. Asas "rahasia" dalam prakteknya sudah tidak menjadi rahasia lagi ketika pemilih sudah dipastikan akan memilih calon peserta tertentu karena terikat dengan pemberian uang dari calon peserta. Asas "jujur" dengan adanya praktek politik uang menjadikan pemilih menjadi tidak jujur karena memilih yang tidak sesuai dengan hati nuraninya, demikian pula calon peserta yang melakukan praktek politik uang akan dimungkinkan memenangkan Pemilukada dengan cara yang tidak jujur. Asas "adil" tidak akan didapat oleh calon peserta lain yang menginginkan pelaksanaan Pemilukada dilakukan dengan cara-cara yang jujur. ${ }^{16}$

Berangkat dari kelebihan dan kekurangan penyelenggaraan Pilkada langsung yang

15 Nur Azizah. (2019). "PPP Nilai Pilkada Langsung Rentan Konflik Horizontal." https://www.medcom.id/nasional/ politik/lKYBpD3N-ppp-nilai-pilkada-langsung-rentan-konflikhorizontal. Diunduh tanggal 5 September 2020.

16 Pan Mohamad Faiz. (2017). "Memperkuat Prinsip Pemilu yang Teratur, Bebas, dan Adil Melalui Pengujian Konstitusionalitas Undang-Undang". Jurnal Konstitusi 14(3). 
dibandingkan dengan Pilkada dikembalikan melalui perwakilan (DPRD), maka penyelenggaraan Pilkada langsung tetap menjadi pilihan yang terbaik, kendatipun efektivitas penyelenggaraan Pemilukada langsung serentak pada Desember 2020 semakin diuji pada kondisi pandemi Covid-19 yang tetap dihadapkan pada persoalan mahalnya biaya politik, terjadinya praktek politik uang, dan timbulnya konflik horizontal.

Penyelenggaraan Pemilukada langsung serentak pada 9 Desember 2020 di 270 daerah yang melibatkan sekitar 105 juta pemilih, tentunya sangat berbeda dengan Pemilukada langsung yang dilaksanakan sebelumnya. Perbedaan tersebut terletak pada proses dan tata cara yang dilakukan oleh KPU/ KPUD selaku penyelenggara Pemilukada langsung. Perbedaan proses dan tata cara yang dimaksud sebagaimana telah diatur dalam Peraturan Komisi Pemilihan Umum Republik Indonesia Nomor 13 Tahun 2020 tentang Perubahan Kedua Atas Peraturan Komisi Pemilihan Umum Nomor 6 Tahun 2020 tentang Pelaksanaan Pemilihan Gubernur dan Wakil Gubernur, Bupati dan Wakil Bupati, dan/atau Wali Kota dan Wakil Wali Kota Serentak Lanjutan Dalam Kondisi Bencana Nonalam Corona Virus Disease 2019 (Covid-19) yang selanjutnya disingkat dengan PKPU No. 6/2020.

Beberapa peraturan yang diatur dalam PKPU No. 6/2020 yang sebelumnya tidak diatur, diantaranya adalah ketentuan Pasal 58 dan Pasal 88C. Dalam ketentuan Pasal 58 pada intinya menyatakan, bahwa: "para kandidat dalam Pilkada serentak 2020 harus mengutamakan kegiatan kampanye di media sosial dan media daring. Jika kampanye tidak dapat dilakukan melalui media sosial dan media daring, maka dibolehkan pertemuan tatap muka dengan jumlah peserta yang hadir paling banyak 50 orang serta menerapkan protokol kesehatan untuk mencegah penyebaran Covid-19".

Selanjutnya dalam rumusan ketentuan Pasal $88 \mathrm{C}$ PKPU No. 6/2020 yang pada intinya menyatakan, bahwa: "melarang tim kampanye melaksanakan kegiatan yang biasanya mengumpulkan massa dalam jumlah besar seperti rapat umum, kegiatan kebudayaan seperti pentas seni atau konser musik, kegiatan olahraga, perlombaan, kegiatan sosial, atau peringatan hari ulang tahun partai politik. Kandidat yang melanggar akan mendapat sanksi berupa peringatan tertulis, penghentian dan pembubaran kampanye, serta larangan melakukan metode kampanye yang dilanggar selama tiga hari. KPU juga membatasi penayangan iklan kampanye di media sosial dan media daring hanya selama 14 hari sebelum dimulainya masa tenang pada tanggal 6 Desember"

Di samping aturan PKPU No. 6/2020 yang dijadikan pedoman bagi penyelenggara dalam tahap pelaksanaan Pemilukada, terdapat aturan lain yang diatur oleh Bawaslu yang terkait dengan sanksi hukum pelanggaran terhadap pelaksanaan Pemilukada di tengah pandemi Covid-19, diantaranya UndangUndang Nomor 6 Tahun 2018 tentang Kekarantinaan Kesehatan, memuat sanksi administratif berupa peringatan dan denda administratif, serta penerapan Pasal 212 dan Pasal 218 KUHP terkait dengan kerumunan massa saat tahapan Pilkada dengan ancaman hukuman penjara dan denda.

Adanya ketentuan-ketentuan yang mengatur tentang tahapan Pemilukada langsung serentak menuju pelaksanaan Pemilukada 9 Desember 2020 menunjukkan adanya pembaharuan dalam sitem penyelenggaraan Pemilukada terkait dengan tahapan Pemilukada yang tentunya memiliki dampaknya terhadap keefektifan, kepastian hukum, dan sistem demokrasi itu sendiri yang memiliki korelasinya terhadap pemenuhan asas dan prinsip-prinsip Pemilu/ Pemilukada, sebagaimana yang telah disinggung di atas. Pertama, dalam kondisi pandemic Covid-19 dengan adanya larangan kerumunan massa dengan melebihi batas maksimal yang telah ditentukan, maka kampanye politik dimaksimalkan melalui dunia maya. Keuntungan yang didapat dengan cara ini diantaranya adalah biaya yang harus dikeluarkan oleh calon peserta dapat diminimalisir, sekaligus berpotensi mengurangi anggaran biaya yang ditanggung oleh pemerintah. Keuntungan lain yang didapat adalah potensi terjadinya konflik horizontal rendah. Sedangkan kelemahannya yang didapat diantaranya adalah berpotensi maraknya berita bohong (hoaks) dan fitnah atau ujaran kebencian yang ditujukan kepada pesaing, sehingga dalam hal ini diperlukan pengawasan yang ekstra ketat dari tenaga ahli informasi dan teknologi akan adanya bahaya kontens. Kelemahan lain yang kemungkinan terjadi, tidak semua calon peserta Pemilukada serta merta mengalihkan kampanye mereka ke media sosial 
dengan pertimbangan tidak semua warga masyarakat memiliki akses internet sehingga dianggap tidak efektif untuk meraih dukungan. Kedua, dengan adanya larangan kerumunan masa ditengah covid-19, sangat dimungkinkan setiap calon peserta melalui timnya melakukan personal approach melalui door to door sebagai bentuk kampanye tatap muka karena dianggap paling efektif. Caranya ini sangat rawan dilakukannya praktek politik uang, terlebih peluang ini dapat dimanfaatkan saat pandemi Covid-19 dalam situasi ekonomi yang serba sulit sebagai dampak dari Covid-19. Dalam kondisi demikian adanya potensi pelanggaran terhadap asas dan prinsip-prinsip penyelengaraan Pemilukada, sekaligus pelanggaran terhadap asas-asas demokrasi itu sendiri.

Berdasarkan pemaparan di atas, diperlukan pembaharuan sistem penyelenggaraan Pemilukada yang efektif, tidak saja diperlukan pada masa pandemi Covid-19 saja namun dalam kondisi normal sekalipun agar terjamin kepastian hukum bagi terselenggaranya pemilukada yang demokratis melalui perbaikanperbaikan terhadap kelemahan-kelemahan yang ada pada penyelenggaraan Pemilukada langsung, khususnya terkait dengan tingginya biaya Pilkada, praktek politik uang dan potensi konflik horizontal dalam penyelengaraan Pemilukada.

Solusi yang dapat dilakukan terhadap kelemahankelemahan yang muncul dalam tahapan Pemilukada langsung di tengah Pandemi Covid-19. Pertama, perlu adanya kejelasan dan ketegasan regulasi, khususnya dalam pelaksanaan kampanye politik di dunia maya, dengan memanfaatkan sosial media. Menghindarkan dan menindak praktek hoax yang terjadi di dunia maya. Kedua, konsistensi penegakkan hukum atas pelanggaran yang dilakukan oleh calon peserta maupun timnya dengan memberikan sanksi yang tegas agar pelaksanaan pemilukada mempunyai kepastian hukum guna terwujudnya Pemilukada yang benar-benar demokratis, karena melalui pengawasan yang ketat dan sanksi hukum yang tegas menjadi kunci terwujudnya penyelenggaraan Pemilukada yang legitimate. Ketiga, diperlukan pengadilan khusus yang menangani tindak pidana Pemilu, mengingat penyelenggaraan Pemilukada pada kenyataannya tidak bisa lepas dari praktek-praktek curang semisal praktek politik uang, penyebaran berita bohong, penyebaran nama baik sampai pada penyelesaian sengketa Pemilukada. Diperlukannya pengadilan khusus ini dimaksudkan guna penyelesaian perkara tindak pidana pemilu dapat dilakukan dengan cepat, sederhana dan biaya murah.

\section{Pemilihan Kepala Daerah yang Berkualitas Melalui Pemilihan Langsung Dalam Melakukan Perubahan Pembangunan Ekonomi dan Kemampuan Manajemen Krisis}

Sistem Pemilukada secara langsung, mampu meningkatkan partisipasi masyarakat di daerah. ${ }^{17}$ Namun, pelaksanaan pemilukada secara demokratis di daerah ini, tidak menjamin adanya pemimpin daerah (Kepala Daerah), yang berkualitas, dengan terhindar dari berbagai kasus. Sering kali, justru bertentangan dengan nilai-nilai yang bersifat fundamental, seperti keadilan, yang berdampak pada tidak tercapainya kesejahteraan rakyat. Apa yang digaungkan pada saat masa kampanye Pemilukada, justru tidak mampu terlaksana ketika sudah terpilih. Kalangan pesimistik menggap bahwa "Pemilukada is a problem, not solution". ${ }^{18}$

Penelitian yang telah dilakukan oleh penulis, mengarahkan pada lima prinsip atau perilaku dasar yang harus dipenuhi bagi seorang Kepala Daerah: 1 . Prinsip dan Perilaku akuntabilitas publik; 2. Prinsip dan Perilaku yang berpegang dan melaksanakan good governance; 3. Prinsip dan Perilaku networking (jaringan kerja); 4. Prinsip dan Perilaku Organisatoris, dengan membangun Organisasi Pemerintahan Daerah yang koordinatif dan harmonis; dan 5. Prinsip dan Perilaku futuristik dan inovatif. ${ }^{19}$

Akuntabilitas publik didefinisikan sebagai tanggungjawab pemerintah dalam mengelola, melaporkan dan mengungkapkan segala bentuk aktivitas yang ada pada lingkup wilayahnya. ${ }^{20}$ Konsep ini dimaknai, bahwa Kepala Daerah harus mampu mempertanggungjawabkan kepada rakyat terhadap penggunaan sumber daya dan kebijakan yang dilakukannya (menerapkan pola

17 Joko J. Prihatmoko. (2007). Mendemokrasikan Pemilu dari Sistem Sampai Elemen Teknis. Yogyakarta: Pustaka Pelajar, h. 161.

${ }^{18}$ Mendasarkan pula pada pendapat Gregorius Sahdan dan Nuhtar Haboddin. (2009). Evaluasi Krisis Penyelenggara Pilkada di Indonesia. Yogyakarta: Stiftung, h. 5.

${ }^{19}$ Daniel Solosa. (2005). Pilkada Langsung. Jakarta: Media Presindo, h. 14.

${ }^{20}$ Mahmudi. (2013). Manajemen Kinerja Sektor Publik. Yogyakarta: Sekolah Tinggi Ilmu Manajemen YKPN, h. 9. 
manajemen). Prinsip dan perilaku Kepala Daerah yang dapat melaksanakan good governance diartikan melaksanakan tata pemerintahan yang baik, dengan berdasar pula pada Asas-Asas Umum Pemerintah yang Baik.

Praktek yang terjadi, setiap Kepala Daerah yang terpilih belum mampu melaksanakan good governance. Hal ini dapat dilihat dari praktek-praktek korupsi yang terjadi hampir ada di setiap daerah, ironisnya Kepala Daerah sendiri ikut berperan dalam tindak pidana korupsi. Menurut Wakil Ketua KPK Laode Muhammad Syarif berpendapat, "terdapat enam Provinsi di Indonesia yang potensi korupsinya paling tinggi, yaitu Aceh, Sumatera Utara, Riau, Banten, Papua dan Papua Barat.". ${ }^{21}$

Terdapat beberapa upaya yang dapat ditempuh untuk mendapatkan pemimpinan daerah berkualitas yang mampu membawa perubahan yang signifikan bagi daerahnya, diantaranya sebagai berikut:

\section{Calon Kepala Daerah yang Jujur}

Prilaku jujur sulit untuk ditebak secara objektif, karena keberadaannya berada pada diri seseorang. Setidak-tidak sikap jujur dapat dilihat dari perbuatan atau tindakannya. Ada beberapa kriteria calon Kepala Daerah yang jujur versi Komisi Pemberantasan Korupsi (KPK) yang dapat dijadikan acuan bagi rakyat sebagai calon pemilih di setiap daerah. Menurut Wakil Ketua KPK Lili Pintauli Siregar menyebut, ada 9 kriteria calon kepala daerah yang jujur dan berintegritas, yaitu sebagai berikut: a. Tidak pernah terlibat dalam kasus korupsi; b. Tidak melakukan politik uang; c. Memiliki rekam jejak yang baik mendukung anti korupsi; d. Patuh melaporkan kekayaan dan menolak gratifikasi; e. Visi dan misi mencerminkan semangat anti korupsi; f. Peduli kepada rakyat dan berpihak kepada keadilan; g. Menghindari konflik kepentingan seperti kolusi dan nepotisme; $h$.

\footnotetext{
${ }^{21}$ Dwi Bowo Raharjo. (2019). "KPK Sebut Enam Provinsi di Indonesia Ini Juara Korupsi”, https://jateng.suara.com/ read/2019/04/10/212117/kpk-sebut-enam-provinsi-di-indonesiaini-juara-korupsi? page $=$ all . Diunduh tanggal 15 Nopember 2020.
}

Gaya hidup sederhana dan melayani; i. Berani dan bertanggung jawab. ${ }^{22}$

Kriteria sikap jujur yang harus dimiliki oleh calon Kepala Daerah di atas, diperlukan peran KPK untuk memberikan edukasi secara berkesinambungan kepada masyarakat yang dapat dilakukan dengan memanfaatkan sosial media yang sudah banyak digunakan oleh masyarakat luas. Memilih pemimpin yang jujur, tidak saja sebagai upaya pencegahan korupsi pada Pilkada Serentak 2020, namun berlaku untuk setiap perhelatan pemilu yang akan datang dan seterusnya.

\section{Prinsip dan Perilaku Futuristik dan Inovatif}

Syarat ini diperlukan apabila daerah yang dipimpinnya menginginkan ada perubahan, dan ini menjadi suatu tantangan bagi Kepada Daerah terutama dalam siatuasi pandemi Covid-19. Belajar dari pengalaman, bahwa pandemi Covid-19 telah mengubah segala aspek kehidupan masyarakat, mulai dari cara beraktivitas masyarakat, berusaha, pendidikan sampai pada hubungan antara warga negara dengan pemerintah dibatasi dan diatur sedemikian rupa guna mencegah penyebaran Covid-19.

Seorang Kepala Daerah yang berorientasi ke masa depan, harus memiliki kemampuan merespon situasi pandemi Covid-19 dengan menyelaraskan birokrasi dengan kemajuan teknologi. Kepala daerah harus mempunyai kemampuan untuk memaksimalkan eksistensi sosial media. Berbagai platform digital yang ada saat ini, menawarkan berbagai kemudahan. Namun, kemudahan yang ada, harus dimanfaatkan guna mencapai kemanfaatan yang maksimal. Reformasi birokrasi, sangat memerlukan adanya pemanfaatan teknologi. ${ }^{23}$ Pada kondisi inilah, wawasan Kepala Daerah tentang teknologi sangatlah penting, sehingga

${ }^{22}$ Suhardiman Selasa. (2020). "KPK Sebut Ada 9 Kriteria Calon Kepala Daerah yang Jujur dan Berintegritas". https:// sumut.suara.com/read/2020/10/27/184806/kpk-sebut-ada-9kriteria-calon-kepala-daerah-yang-jujur-dan-berintegritas. Diunduh tanggal 15 Nopember 2020.

${ }^{23}$ Titin Rohayatin. (2017). "Strategi Reformasi Birokrasi Pemerintahan Daerah: Menuju Era Globalisasi”. Jurnal Transformative 13(1). 
mampu berpandangan ke depan dan inovatif. Mampu memfasilitasi masyarakat, khususnya dalam berinteraksi, bekerja dan berusaha, dengan mendasarkan pula pada prinsip kemanfaatan dan kesejahteraan umum.

\section{Perubahan Syarat Calon Kepala Daerah}

UUD Tahun 1945 mulai Pasal 27 ayat (1) dan (2); Pasal 28, Pasal 28D ayat (3), Pasal $28 \mathrm{E}$ ayat (3), memberikan hak konstitusional kepada warga negara untuk memilih dan dipilih, termasuk dalam agenda Pemilukada. Usulan terhadap perubahan syarat-syarat menjadi calon Kepala Daerah tidak dimaknai sebagai pelanggaran hak-hak warga negara untuk dipilih, namun sebagai upaya mendapatkan pemimpin daerah yang berkualitas, mampu membawa perubahan signifikan untuk kesejahteraan rakyatnya.

Sehubungan dengan hal di atas, dipandang perlu untuk memberikan usulan perubahan terhadap beberapa syarat untuk menjadi calon Kepala Daerah yang telah diatur dalam Peraturan Komisi Pemilihan Umum Nomor 1 Tahun 2020 tentang Perubahan Ketiga atas PKPU Nomor 3 Tahun 2017 tentang Pencalonan Pemilihan Gubernur dan Wakil Gubernur, Bupati dan Wakil Bupati, atau Wali Kota dan Wakil Wali Kota (selanjutnya disebut PKPU No. 1 Tahun 2020)

a. Syarat Pendidikan Minimal

Berdasarkan Pasal 4 huruf c PKPU No. 1 Tahun 2020 disebutkan bahwa syarat menjadi Calon Gubernur dan Wakil Gubernur, Bupati dan Wakil Bupati, atau Wali Kota dan Wakil Wali Kota berpendidikan paling rendah Sekolah Lanjutan Tingkat Atas atau sederajat.

Syarat pendidikan formal minimal Sekolah Lanjutan Tingkat Atas atau sederajat untuk seorang Kepala Daerah sudah tidak relevan dengan kondisi saat ini yang menuntut banyak perubahan di segala bidang seiring dengan perkembangan informasi dan teknologi yang begitu cepat. ${ }^{24}$ Oleh karenanya, syarat pendidikan formal

${ }^{24}$ Djauhari. (2011). "Problematika Pemilihan Kepala Daerah Secara Langsung (Dalam Perspektif Sosiologis)". Jurnal Dinamika Hukum 11(1). minimal untuk Kepala Daerah yang ideal minimal Sarjana. Sebab, tingkat pendidikan formal seseorang dapat mempengaruhi pola pikir dan cara pandang yang lebih kritis menghadap segala persoalan daerah yang dihadapinya, tidak hanya sekedar memimpin. Syarat pendidikan untuk menjadi seorang pemimpin berkorelasi dengan teori sosial, bahwa: ${ }^{25} 1$. Pemimpin itu harus disiapkan, di didik, dan dibentuk, tidak terlahirkan begitu saja; 2. Setiap orang bisa menjadi pemimpin melalui usaha penyiapan dan pendidikan serta didorong oleh kemauan sendiri.

b. Batas Usia Minimal

Dari sisi usia, berdasarkan Pasal 4 huruf d PKPU No. 1 Tahun 2020, disebutkan bahwa berusia paling rendah 30 (tiga puluh) tahun untuk Calon Gubernur dan Wakil Gubernur dan 25 (dua puluh lima) tahun untuk Calon Bupati dan Wakil Bupati atau Calon Wali Kota dan Wakil Wali Kota terhitung sejak penetapan Pasangan Calon.

Sekalipun, Kepala Daerah merupakan jabatan politik karena pada umumnya diusung oleh partai poltik, namun usia jabatan sebagai Kepala Daerah yang masih relatif muda dirasakan belum cukup umur untuk memimpin daerah yang memiliki tugas dan tanggung jawab yang berat terlebih tidak memiliki pengalaman dalam berorganisasi. Relevan dengan teori ekologis yang mengarahkan bahwa kesuksesan seseorang menjadi pemimpin, apabila sejak lahir, dan usia sekolah, telah diarahkan dan diajarkan tentang kepemimpinan. Mengarahkan pada lingkungan yang mengajarkan sebagai pemimpin. ${ }^{26}$

Sehubungan dengan hal di atas, perlu kiranya syarat batas minimal usia calon Kepala Daerah dilakukan penyesuaian kembali, mengingat tuntutan tugas dan tanggung jawab Kepala Daerah pada situasi perubahan arus informasi dan teknologi yang begitu cepat dituntut memiliki Kepala Daerah yang memiliki pengalaman dan

\footnotetext{
${ }^{25}$ Kartini Kartono. (2016). Pemimpin dan Kepemimpinan. Jakarta: Rajawali Pers, h. 33.

${ }^{26}$ ibid.
} 
wawasan yang luas, tidak hanya sebatas menyampaikan visi dan misinya pada saat kampanye karena yang lebih penting adalah aplikasinya.

\section{Seleksi Ketat Dari Partai Politik}

Pada umumnya, calon kandidat berasal dari partai politik. Hal ini merujuk pada ketentuan Pasal 39 huruf (a) Undang-Undang Nomor 10 Tahun 2016 tentang Pilkada, bahwa peserta pilkada adalah pasangan calon yang diusulkan oleh partai politik atau gabungan partai politik. Artinya partai politik mempunyai kewenangan yang besar dan strategis untuk mengajukan pasangan calon. Menurut Pasal 29 ayat (2) Undang-Undang Nomor 2 Tahun 2008 tentang Partai Politik menerangkan, bahwa rekrutmen Bakal Calon Kelapa Daerah dilakukan secara demokratis dan terbuka sesuai dengan $\mathrm{AD} /$ ART dan peraturan perundang-undangan yang berlaku.

Sampai saat ini, belum ada undang-undang yang secara khusus dan terperinci tentang proses seleksi calon Kepala Daerah melalui Partai Politik, karena dalam prakteknya diserahkan sepenuhnya pada mekanisme partai. Sehingga, makna demokratis dan terbuka ditafsirkan sesuai dengan kepentingan partai politik semata, mengingat prosesnya dilakukan tidak ada keterlibat masyarakat. ${ }^{27}$ Kelemahan inilah sebagai salah satu penyebab calon Kapala Daerah yang tidak mewakili aspiratif masyarakat di daerah. Oleh sebab itu, dengan mendasarkan pula pada pendapat Mochammad Faris,${ }^{28}$ perlu dibentuk peraturan yang menjadi dasar dalam melakukan seleksi bakal calon Kepala Daerah oleh internal Partai Politik atau gabungan Partai Politik. Memenuhi unsur, antara lain: (1) sistem seleksi, (2) panitia dan kewenangan penyeleksi, (3) standar penilaian, (4) akuntabilitas proses seleksi, (5) evaluasi dan kaderisasi. Saat ini, masyarakat tidak pernah mengetahui, proses yang ada dalam setiap partai politik. Mereka

${ }^{27}$ Fitriyah. (2020). "Partai Politik, Rekrutmen Politik dan Pembentukan Dinasti Politik pada Pemilihan Kepala Daerah (Pilkada). Politika: Jurnal Ilmu Politik 11(1).

${ }^{28}$ Mochammad Faris. 2018. "Oligarki Partai Politik Dalam Pilkada”, https://www.unja.ac.id/2018/04/09/oligarki-partaipolitik-dalam-pilkada/. Diunduh tanggal 15 Nopember 2020. baru mengetahui hanya ketika mendekati masa pemilihan. Di sisi lain, hal ini turut berpotensi mencederai hak masyarakat untuk memperoleh akses informasi atas calon pemimpinnya. Apalagi partai politik turut menjadi jembatan tegaknya kedaulatan rakyat.

\section{Uji Publik Kandidat}

Berdasarkan Pasal 9 huruf a Undang-Undang Nomor 1 Tahun 2015 tentang Kelengkapan Peraturan Pemerintah Pengganti UndangUndang Nomor 1 Tahun 2014 tentang Pemilihan Gubernur Bupati dan Walikota yang telah beberapa kali diubah, terakhir Undang-Undang Nomor 10 Tahun 2016, uji publik menjadi syarat utama sebelum dilakukan pemilihan langsung oleh rakyat. Uji publik menjadi sarana untuk memperkuat karakter calon pemimpin, sehingga lebih dikenal oleh masyarakat (konstituennya). Di sisi lain, uji publik juga dapat mendorong masyarakat untuk secara aktif memberikan pertanyaan dan mendengar jawaban dari calon pemimpinnya. Uji publik dilakukan secara transparan, dan akuntabel. ${ }^{29}$

Terdapat beberapa hal yang dapat disampaikan pada pelaksanaan uji publik yang selama ini sudah dilakukan, namun terdapat celah yang mungkin belum dijamah dan dapat dijadikan sebagai bahan masukan guna mendapatkan nilai lebih terhadap kualitas seorang Kepala Daerah, yaitu kompetensi dan kemampuan dalam bidang manajemen krisis (kemampuan manajemen penanggulangan bencana).

Dalam situasi kondisi pandemic Covid-19, Kepala Daerah tidak saja harus memiliki kompetensi sebagai seorang pemimpin, namun juga memiliki kemampuan dalam bidang manajemen krisis. Pernyataan tegas Presiden Republik Indonesia, Joko Widodo dihadapan seluruh Gubernur seIndonesia yang mengarahkan Kepala Daerah untuk melaksanakan manajemen krisis. Kaitannya dengan roda pemerintahan di daerah dengan Covid-19, bahwa agar Kepala Daerah melaksanakan manajemen krisis dalam menjalankan roda pemerintahan di era pandemi harus memiliki sikap yang luwes, pandai

${ }^{29}$ Fauzin. (2020). "Uji Publik Sebagai Model Pelibatan Masyarakat Dalam Seleksi Komisioner Komisi Pemberantasan Korupsi." Rechtidee 15(1). 
mengendalikan roda pembangunan di daerah, agar tidak terjerumus terlalu jauh dalam pelaksanaan pembangunan dalam masa pandemi. ${ }^{30}$

Kemampuan Kepala Daerah dalam menjalankan krisis pandemi Covid-19 memiliki korelasinya tugas Kepala Daerah menjalankan pemerintahan. Mengacu pada pendapat Iriantara, dapat dipahami bahwa manajemen krisis yaitu memperkuat kemampuan teknis dalam mengidentifikasi, menilai, memahami dan mengatasi situasi krusial/darurat. Manajemen krisis mendasarkan pada situasi (crisis bargaining and negotiation), membuat keputusan di saat krisis (crisis decision making), dan memantau perkembangan krisis (crisis dynamics). ${ }^{31}$

Pandemi Covid-19 telah menuntun dan menuntut Kepala Daerah untuk bertindak lebih tanggap dan terarah dalam menghadapi situasi. Dampak yang ditimbulkan dirasakan oleh berbagai kalangan, dan seluruh sektor (ekonomi, sosial, hingga pendidikan) sehingga termasuk dalam krisis yang berskala luas (landscape-scale). ${ }^{32}$ Dibutuhkan kesigapan oleh Kepala Daerah untuk mengatasi persoalan yang terjadi, sehingga tidak menimbulkan dampak berantai yang justru merugikan. Dibutuhkan ketepatan dalam pengambilan keputusan, secara cepat dan cermat. ${ }^{33}$

Kepala Daerah dalam menghadapi situasi krisi semacam ini, khususnya seperti Covid-19, harus bertindak reaktif dengan prinsip kehati-hatian. Tidak menutup kemungkinan Kepala Daerah mengambil langkah kebijakan menyusun diskresi, dengan turut pula memperhatikan pemulihan/perbaikan ke depan. Hal ini berkorelasi dengan salah satu prilaku yang harus dimiliki oleh Kepala Daerah dengan tuntutan era reformasi saat ini menurut Daniel Solosa yang telah disampaikan di atas adalah perilaku Kepala Daerah yang berorientasi ke masa depan.

${ }^{30}$ Edwin. (2020). "Presiden Minta Gubernur Laksanakan Manajemen Krisis Dalam Pelaksanaan Roda Pemerintahan Di Era Pandemi Covid-19. https://bangka.sonora.id/read/502244998/ presiden-minta-gubernur-laksanakan-manajemen-krisisdalam-pelaksanaan-roda-pemerintahan-di-era-pandemi-covid19? page $=$ all. Diunduh tanggal 23 Agustus 2020 .

${ }^{31}$ Yosal Iriantara. (2004). Manajemen Strategis Public Relations. Jakarta: Ghalia Indonesia, h. 116.

${ }^{32}$ Deborah E. Gibbons, ed. (2007). Communicable Crises: Prevention, Response, and Recovery in the Global Arena. Charlotte NC: Information Age Publishing.

${ }^{33}$ Ardhiwinda Kusumaputra dan Endang Retnowati. (2020). "Analisis Yuridis Dasar Pertimbangan Kebijakan Lockdown Pada Situasi Darurat Kesehatan di Tingkat Daerah." MasalahMasalah Hukum 49(3).

\section{PENUTUP \\ Kesimpulan}

Pemilukada langsung masih menjadi pilihan utama meskipun pemilu daring tetap harus menjadi wacana pengaturan ke depan agar terjadi pembaharuan terhadap sistem penyelenggaraan Pemilukada yang efektif, berkepastian hukum dan berdemokrasi secara sehat. Sistem pemilukada dapat dilakukan dengan menggunakan pola asimetris dan/atau pola delegasi dengan memperhatikan tingkat kerawanan praktek politik uang dan tingkat kerawanan konflik horizontal di masing-masing daerah yang diatur oleh undang-undang sebagai payung hukumnya. Mengenai praktek politik uang dalam setiap penyelenggaraan Pemilukada diperlukan "pengadilan khusus" di setiap daerah, khusus untuk menangani sengketa Pemilukada dan penanganan tindak pidana pemilu demi terwujudnya kepastian hukum dalam penegakan Undang-Undang Pemilu.

Melalui Pemilukada yang diselenggarakan secara langsung, perlu diupayakan serangkaian cara agar diperoleh Kepala Daerah yang berkualitas yakni melalui perubahan syarat pendidikan minimal sarjana, lulus uji publik yang dilaksanakan dari internal partai maupun lulus uji publik yang diselengarakan oleh KPUD yang melibatkan berbagai pihak dari berbagai disiplin ilmu. Tidak hanya itu saja, dalam situasi daerah yang rawan bencana dan dalam kondisi pandemi Covid-19 khususnya, sangat diperlukan seorang Kepala Daerah yang memiliki kemampuan dalam bidang manajemen krisis karena pada dasarnya setiap warga negara berhak untuk mendapat perlindungan dan keselamatan dari segala bentuk ancaman yang membahayakan jiwa sebagaimana telah diamanatkan dalam konstitusi.

\section{Rekomendasi}

Khusus untuk pemilu daring perlu adanya rekonstruksi aturan pemilu daring yang ditetapkan melalui peraturan di tingkat Pusat, seperti UndangUndang atau Peraturan Presiden, yang memuat dasar aturan pemilihan secara daring. Apalagi di masa pandemi Covid-19, tahapan Pemilukada yang dilakukan secara daring sangat diperlukan. Arah penyusunan kebijakan tersebut, berlangsung efektif dengan memastikan semua pemilih memiliki akses internet melalui kerjasama antara KPU/KPUD dengan operator selular. 
Perlu adanya peninjauan tentang syarat usia bagi calon kandidat, dengan didukung perlunya memiliki kemampuan dalam berorganisasi. Uji publik dilakukan pada tingkat internal partai dan KPUD yang sebaiknya dijadikan sebagai bagian dari tahapan pemilukada. Setiap Kepala Daerah wajib memahami manajemen krisis untuk mengantisipasi terjadinya bencana/wabah guna melindungi warganya yang dapat diketahui kemampuannya dari pelaksanaan uji publik.

\section{DAFTAR PUSTAKA}

\section{Peraturan Perundang-undangan:}

Undang-Undang Dasar Tahun 1945.

Kitab Undang-Undang Hukum Pidana.

Undang-Undang Nomor 2 Tahun 2008 tentang Partai Politik.

Undang-Undang Nomor 1 Tahun 2015 tentang Kelengkapan Peraturan Pemerintah Pengganti Undang-Undang Nomor 1 Tahun 2014 tentang Pemilihan Gubernur Bupati dan Walikota yang telah beberapa kali diubah, terakhir UndangUndang Nomor 10 Tahun 2016.

Undang-Undang Nomor 10 Tahun 2016 tentang Pilkada.

Undang-Undang Nomor 7 Tahun 2017 tentang Pemilihan Umum.

Undang-Undang Nomor 6 Tahun 2018 tentang Kekarantinaan Kesehatan.

Peraturan Pemerintah Nomor 49 Tahun 2008 tentang Perubahan Atas Peraturan Pemerintah Nomor 6 Tahun 2005tentang Pemilihan, Pengesahan, Pengangkatan dan Pemberhentian Kepala Daerah.

Peraturan Komisi Pemilihan Umum Nomor 1 Tahun 2020 tentang Perubahan Ketiga atas PKPU Nomor 3 Tahun 2017 tentang Pencalonan Pemilihan Gubernur dan Wakil Gubernur, Bupati dan Wakil Bupati, atau Wali Kota dan Wakil Wali Kota.

Peraturan Komisi Pemilihan Umum Republik Indonesia Nomor 13 Tahun 2020 tentang Perubahan Kedua Atas Peraturan Komisi Pemilihan Umum Nomor 6 Tahun 2020 Tentang PelaksanaanPemilihan Gubernur dan Wakil Gubernur, Bupati dan Wakil Bupati, dan/ atau Wali Kota dan Wakil Wali Kota Serentak
Lanjutan Dalam Kondisi Bencana Nonalam Corona Virus Disease 2019 (Covid-19).

\section{Buku:}

Abdul Bari Azed. (2005). Pemilu dan Partai Politik di Indonesia. Jakarta: PSH Tata Negara Universitas Indonesia.

Daniel Solosa. (2005). Pilkada Langsung. Jakarta: Media Presindo.

Deborah E. Gibbons, ed. (2007). Communicable Crises: Prevention, Response, and Recovery in the Global Arena. Charlotte NC: Information Age Publishing.

George Sorensen. (2014). Demokrasi dan Demokratisasi (Proses dan Prospek dalam Sebuah Dunia yang Berubah). Yogyakarta: Pustaka Pelajar.

Gregorius Sahdan dan Nuhtar Haboddin. (2009). Evaluasi Krisis Penyelenggara Pilkada di Indonesia. Yogyakarta: Stiftung.

Hendra Budiman. (2015). Pilkada tidak Langsung dan Demokrasi Palsu. Yogyakarta: Pustaka Yustisia.

Jimly Asshiddiqie. (2011). Pengantar Ilmu Hukum Tata Negara. Jakarta: Rajawali Pers.

Joko J. Prihatmoko. (2003). Pemilu 2004 dan Konsolodasi Demokrasi. Jakarta: LP2I Press. (2007). Mendemokrasikan Pemilu dari Sistem Sampai Elemen Teknis. Yogyakarta: Pustaka Pelajar.

Kartini Kartono. (2016). Pemimpin dan Kepemimpinan. Jakarta: Rajawali Pers.

Mahmudi. (2013). Manajemen Kinerja Sektor Publik. Yogyakarta: Sekolah Tinggi Ilmu Manajemen YKPN.

Suharizal. (2011). Pemilukada Regulasi, Dinamika, dan Konsep Mendatang. Jakarta: Rajawali Pers.

Yosal Iriantara. (2004). Manajemen Strategis Public Relations. Jakarta: Ghalia Indonesia.

\section{Jurnal:}

Ardhiwinda Kusumaputra dan Endang Retnowati. (2020). "Analisis Yuridis Dasar Pertimbangan Kebijakan Lockdown Pada Situasi Darurat Kesehatan di Tingkat Daerah." MasalahMasalah Hukum 49(3). 
Djauhari. (2011). "Problematika Pemilihan Kepala Daerah Secara Langsung (Dalam Perspektif Sosiologis)". Jurnal Dinamika Hukum 11(1).

Fauzin. (2020). "Uji Publik Sebagai Model Pelibatan Masyarakat Dalam Seleksi Komisioner Komisi Pemberantasan Korupsi." Rechtidee 15(1).

Fitriyah. (2020). "Partai Politik, Rekrutmen Politik dan Pembentukan Dinasti Politik pada Pemilihan Kepala Daerah (Pilkada). Politika: Jurnal Ilmu Politik 11(1).

Pan Mohamad Faiz. (2017). "Memperkuat Prinsip Pemilu yang Teratur, Bebas, dan Adil Melalui Pengujian Konstitusionalitas Undang-Undang”. Jurnal Konstitusi 14(3).

Ridho Imawan Hanafi. (2014). "Pemilihan Langsung Kepala Daerah di Indonesia: Beberapa Catatan Kritis Untuk Partai Politik." Jurnal Penelitian Politik 11(2).

Titin Rohayatin. (2017). "Strategi Reformasi Birokrasi Pemerintahan Daerah: Menuju Era Globalisasi". Jurnal Transformative 13(1).

Yusdianto. (2010). "Identifikasi Potensi Pelanggaran Pemilihan Kepala Daerah (Pemilukada) dan Mekanisme Penyelesaiannya". Jurnal Konstitusi. 2(2), h. 44.

\section{Website:}

Andri Saubani. (2020). "Potensi Maraknya Praktik Politik Uang Pilkada Kala Pandemi”, 03 Jul 2020, https://republika.co.id/berita/qculq7409/potensimaraknya-praktik-politik-uang-pilkada-kalapandemi. Diunduh tanggal 5 September 2020.

Anisyah Al Faqir. (2019). "Mahalnya Pilkada Langsung Hingga Habiskan Uang Rp 100 miliar". https://www.liputan6.com/bisnis/ read/4134744/mahalnya-pilkada-langsunghingga-habiskan-uang-rp-100-miliar. Diunduh tanggal 5 September 2020.

Anonim. 2019. "Pilkada Langsung atau Tidak, Mau Dibawa ke Mana Demokrasi Kita?" https://www. kompas.com/tren/read/2019/12/02/164404365/ pilkada-langsung-atau-tidak-mau-dibawake-mana-demokrasi-kita?page $=$ all. Diunduh tanggal 5 September 2020.

Dwi Bowo Raharjo. (2019). "KPK Sebut Enam Provinsi di Indonesia Ini Juara Korupsi”, https:// jateng.suara.com/read/2019/04/10/212117/ kpk-sebut-enam-provinsi-di-indonesia-inijuara-korupsi? page=all. Diunduh tanggal 15 Nopember 2020.

Edwin. (2020). "Presiden Minta Gubernur Laksanakan Manajemen Krisis Dalam Pelaksanaan Roda Pemerintahan Di Era Pandemi Covid-19. https:// bangka.sonora.id/read/502244998/presidenminta-gubernur-laksanakan-manajemen-krisisdalam-pelaksanaan-roda-pemerintahan-di-erapandemi-covid-19? page $=$ all . Diunduh tanggal 23 Agustus 2020.

Merdeka.com, "Alasan Kemendagri Evaluasi Pilkada Langsung, Banyak Kepala Daerah Terjerat Korupsi", 21 November 2019. https:// www.merdeka.com/politik/alasan-kemendagrievaluasi-pilkada-langsung-banyak-kepaladaerah-terjerat-korupsi.html. Diunduh tanggal 5 September 2020.

Mochammad Faris. 2018. "Oligarki Partai Politik Dalam Pilkada", https://www.unja. ac.id/2018/04/09/oligarki-partai-politik-dalampilkada/. Diunduh tanggal 15 Nopember 2020.

Nur Azizah. (2019). "PPP Nilai Pilkada Langsung Rentan Konflik Horizontal." https://www. medcom.id/nasional/politik/lKYBpD3Nppp-nilai-pilkada-langsung-rentan-konflikhorizontal. Diunduh tanggal 5 September 2020. Suhardiman Selasa. (2020). "KPK Sebut Ada 9 Kriteria Calon Kepala Daerah yang Jujur dan Berintegritas". https://sumut.suara.com/ read/2020/10/27/184806/kpk-sebut-ada-9kriteria-calon-kepala-daerah-yang-jujur-danberintegritas. Diunduh tanggal 15 Nopember 2020. 